\title{
PENINGKATAN KUALITAS PEMBELAJARAN PRAKTIK RANGKAIAN LISTRIK MELALUI PENERAPAN LESSON STUDY
}

\author{
Faranita Surwi ${ }^{1}$, Totok Heru, T.M. ${ }^{2}$, Sunaryo Soenarto ${ }^{3}$, Nurhening Yuniarti ${ }^{4}$, \\ Muhfizaturrahmah $^{5}$, Rustam Asnawi ${ }^{6}$ \\ 1, 2,3,4,5,6 Dosen Jurusan Pendidikan Teknik Elektro, FT UNY \\ Email: faranita@uny.ac.id
}

\begin{abstract}
This study aims to: (1) get the pattern of applying lesson study based on Practice of Electric Circuits course, and (2) to find out the achieved competence by the students in the Lesson Study base of Electric Circuit Practice. Learning system development method applied is lesson research with lesson study Lewis model (2002). Based on the results of the study, the pattern appliying lesson study based learning in Electric Circuits Practice courses is: (1) obliging students to learn the material to be practiced; (2) the lecturer communicates the purpose of the practicum and performs the apperception well; (3) holding a pretest; (4) brief explanation of supporting theories; (5) practicum carried out in groups with the number of members 3-4 people; (6) carry out practicum according to the procedure and make a temporary report; (7) feedback on the data obtained, (8) students are required to analyze data and make practical reports. The application of lesson study can improve students' competence in Electric Circuit Practice courses, while the average score for cycles I, II and III is 8.75; 8.77; and 9.28 .
\end{abstract}

Keywords: competence, lesson study, electrical circuit practice

\begin{abstract}
ABSTRAK
Kajian ini bertujuan untuk: (1) mendapatkan pola penerapan pembelajaran berbasis lesson study pada mata kuliah Praktik Rangkaian Listrik, dan (2) mengetahui kompetensi yang dicapai mahasiswa pada mata kuliah Praktik Rangkaian Listrik berbasis lesson study. Metode pengembangan sistem pembelajaran yang diterapkan adalah lesson research dengan lesson study model Lewis (2002). Berdasarkan hasil kajian diperoleh pola penerapan pembelajaran berbasis lesson study pada mata kuliah Praktik Rangkaian Listrik adalah: (1) mewajibkan mahasiswa mempelajari materi yang akan dipraktikkan; (2) dosen menyampaikan tujuan praktikum dan melakukan apersepsi dengan baik; (3) mengadakan pretest; (4) memberi penjelasan singkat teori pendukung; (5) praktikum dilaksanakan secara kelompok dengan jumlah anggota 3-4 orang; (6) melaksanakan praktikum sesuai prosedur dan membuat laporan sementara; (7) adanya umpan balik terhadap data yang diperoleh, (8) mahasiswa diwajibkan untuk menganalisis data dan membuat laporan praktikum. Penerapan lesson study dapat meningkatkan kompetensi mahasiswa pada mata kuliah Praktik Rangkaian Listrik, adapun pencapaian nilai ratarata untuk siklus I, II dan III berturut-turut sebesar 8,75; 8,77; dan 9,28.
\end{abstract}

Kata Kunci: kompetensi, lesson study, praktik rangkaian listrik

\section{PENDAHULUAN}

Kurikulum 2014 Program Studi Pendidikan Teknik Elektro S1 mulai diterapkan pada tahun akademik 2015/2016. Kurikulum tersebut membagi mata kuliah menjadi 2 bagian yaitu: mata kuliah dasar dan mata kuliah konsentrasi. Salah satu mata kuliah dasar adalah Praktik Rangkaian Listrik dengan kode mata kuliah EKO 6217 dengan bobot 2 SKS. Pembelajaran Praktik Rangkaian Listrik mengembangkan kompetensi utuh baik kognitif, afektif maupun psikomotorik. Lingkup mata kuliah Praktik Rangkaian Listrik meliputi: (1) pengenalan bahan dan alat listrik, (2) pengenalan dan penggunaan berbagai alat pengukuran listrik baik DC dan AC, (3) beban listrik RLC, (4) berbagai jenis rangkaian listrik 
DC dan AC, (5) rangkaian seri, paralel, dan campuran, (5) pengisian dan pengosongan induktor dan kapasitor, (6) pengaruh frekuensi terhadap beban RLC seri dan paralel, (7) resonansi, sambungan bintang dan segitiga, (8) tes urutan fase, (9) pengukuran daya 3 fase, (10) beban seimbang dan tidak seimbang, dan kualitas daya.

Hasil pembelajaran mata kuliah Praktik Rangkaian Listrik, pada tahun akademik 2015/2016 belum memuaskan. Selain itu pada pembelajaran Praktik Rangkaian Listrik menunjukkan bahwa: (1) kemampuan awal mahasiswa terutama penguasaan teori fisika dan teori rangkaian 1sitrik yang yang kurang memuaskan, (2) beberapa mahasiswa yang mengalami kesulitan menerima materi perkuliahan, (3) mahasiswa kurang aktif di kelas, dan (4) sebagian mahasiswa mengganggap Praktik Rangkaian Listrik adalah mata kuliah yang sulit.

Permasalahan yang dihadapi pada pelaksanaan mata kuliah Praktik Rangkaian Listrik tersebut perlu diatasi. Hal ini disebabkan kompetensi mahasiswa dalam Praktik Rangkaian Listrik akan bersinergis dengan mata kuliah lain pada semester berikutnya seperti: mesin listrik, perawatan perbaikan, instalasi listrik, proteksi tenaga listrik, elektronika daya dan sebagainya. Kondisi tersebut dapat dijadikan sebagai bahan evaluasi bagi dosen untuk mencari kemungkinan penyebabnya dan solusinya. Ditinjau dari sisi pengajar, permasalahan tersebut akan terkait dengan cara mengajar, pemilihan strategi pembelajaran, pemilihan metode/model pembelajaran, penggunaan media, umpan balik, pemberian tugas, penilaian, dan evaluasi.

Salah satu upaya untuk mengatasi permasalahan tersebut adalah dengan mencoba untuk menerapkan pembelajaran Praktik Rangkaian Listrik berbasis lesson study berlandaskan prinsip-prinsip kolegalitas dan mutual learning untuk membangun learning community. Penerapan lesson study ini diharapkan dapat meningkatkan kualitas pembelajaran dan meningkatkan pencapaian kompetensi mahasiswa khususnya pada mata kuliah Praktik Rangkaian Listrik.

\section{METODE}

Penelitian ini dilaksanakan pada semester gasal tahun akademik 2016/2017 di Laboratorium Dasar Listrik Program Studi Pendidikan Teknik Elektro Fakultas Teknik Universitas Negeri Yogyakarta pada bulan November 2016. Obyek yang menjadi fokus dalam penelitian ini adalah mata kuliah Praktik Rangkaian Listrik. Metode pengembangan sistem pembelajaran yang diterapkan dalam penelitian ini adalah lesson research dengan lesson study model Lewis (2002).

Penerapan lesson study dengan model Lewis ini memiliki 6 tahapan yaitu: (1) membentuk kelompok lesson study, (2) memfokuskan lesson study, (3) merencanakan pembelajaran, (4) pelaksanaan pembelajaran dan observasi, (5) refleksi dan menganalisis pembelajaran yang telah dilakukan, dan (6) merencanakan tahap-tahap berikutnya.

Teknik yang digunakan untuk memperoleh data penelitian antara lain: (1) kolaborasi antara dosen pelaksana pembelajaran dengan kolaborator atau pengamat, (2) observasi, (3) dokumentasi dan (4) wawancara. Instrumen yang digunakan untuk memperoleh data antara lain lembar observasi, pedoman wawancara. Teknik analisis data yang digunakan adalah teknik analisis deskriptif, selain itu digunakan analisis refleksi kolaboratif oleh kelompok dan pakar yang ditunjuk terhadap kualitas pembelajaran.

\section{HASIL DAN PEMBAHASAN}

Berikut ini disampaikan hasil implementasi lesson study pada mata kuliah Praktik Rangkaian Listrik.

\section{Siklus Pertama}

Pelaksanaan siklus pertama diawali dengan kegiatan perencanaan (plan) yang dilakukan dengan cara melakukan koordinasi teknis pelaksanaan pembelajaran pada siklus I. 
Beberapa hal yang dihasilkan dalam rapat koordinasi tersebut adalah: (1) kesepakatan pembagian tugas (ketua tim, dosen model, kolabolator, tim dokumentasi), (2) pembuatan lembar observasi, dan (3) teknik pelaksanaan pembelajaran, dan (4) teknis pelaksanaan evaluasi pembelajaran.

Pada awal pembelajaran dosen model menyampaikan topik Praktik Rangkaian Listrik yang akan dilaksanakan, memberikan motivasi dan semangat belajar, kedisiplinan kepada mahasiswa serta melakukan diagnosis awal tentang kekuatan dan kelemahan yang dimiliki mahasiswa. Secara garis besar kekuatan yang dimiliki mahasiswa adalah masih adanya kemauan belajar. Sedangkan kelemahannya adalah kurangnya pengetahuan yang relevan dan mendukung mata kuliah Praktik Rangkaian Listrik seperti: Teori Rangkaian Listrik, Fisika, Dasar Listrik. Pada pertemuan yang pertama tersebut dosen menjelaskan Job sheet tentang pengisisan dan pengosongan kapasitor dan induktor dilanjutkan dengan membagi kelompok praktik. Mahasiswa dibagi menjadi 5 kelompok yang masing-masing kelompok terdiri atas 3 sampai 4 mahasiswa. Setelah itu, mahasiswa melakukan praktikum sesuai dengan arahan yang diberikan oleh dosen. Selama kegiatan praktik, dosen mendampingi mahasiswa sehingga kesulitan yang dialami mahasiswa dapat segera ditanyakan kepada dosen. Dalam pelaksanaan praktik tersebut masih ada beberapa mahasiswa yang kurang aktif dan kelihatan tidak fokus dengan kegiatan praktikum karena merasa kebingungan dan tidak menguasai materi praktik. Proses pengambilan data pada beberapa kelompok membutuhkan waktu yang cukup lama karena waktu praktik yang disediakan banyak digunakan untuk mendiskusikan materi praktik. Setelah praktikum berjalan 150 menit, dosen mengingatkan kembali agar masing-masing kelompok mengumpulkan data praktikum. Setelah mahasiswa selesai melakukan pengambilan data kemudian mahasiswa diminta mengembalikan alat dan bahan praktik pada tempatnya dan kembali ke meja masing- masing. Dosen melakukan pengecekan data praktikum untuk setiap kelompok dan menutup proses pembelajaran.

Setelah pembelajaran selesai, dilakukan refleksi terhadap pembelajaran yang telah dilaksanakan pada siklus I. Adapun masukan yang diberikan oleh kolabolator adalah sebagai berikut:

1. Mahasiswa terlihat sangat pasif dan kurang proaktif, sehingga dosen harus mencari strategi yang tepat untuk meningkatkan motivasi belajar mahasiswa,

2. Dosen model perlu menyampaikan judul praktikum dengan cara menuliskan judul di papan white board atau dengan memanfaatkan power point atau media yang lain,

3. Tujuan praktikum dijelaskan secara lebih detail sehingga semua mahasiswa mengetahui tujuan praktikum,

4. Perlu memberikan penjelasan hal-hal yang terkait dengan parktikum (apersepsi),

5. Perlu memanfaatkan papan white board untuk memberikan penjelasan terhadap materi yang belum dipahami,

6. Perlu memberikan umpan balik terhadap data hasil pengamatan untuk semua kelompok,

7. Perlu memperhatikan perhatian yang lebih besar kepada mahasiswa yang tidak memperhatikan penjelasan dosen.

\section{Siklus Kedua}

Pelaksanaan siklus kedua diawali dengan kegiatan perencanaan (plan) yang dilakukan dengan cara melakukan koordinasi teknis pelaksanaan pembelajaran pada siklus II. Pada awal pembelajaran, dosen model menyampaikan topik Praktik Rangkaian Listrik yang akan dilaksanakan. Pada siklus II, dosen model memanfaatkan LCD projector. Pada pertemuan kedua tersebut dosen menjelaskan Job sheet tentang Pengaruh frekwensi terhadap beban RLC seri dan paralel secara lebih detail. Dosen menampilkan jobsheet dalam layar LCD. Waktu yang digunakan untuk memberikan penjelasan atau pengantar praktikum adalah 30 
menit. Setelah itu, dosen membagi mahasiswa menjadi 5 kelompok yang masing-masing kelompok terdiri atas 3 sampai 4 mahasiswa kemudian mahasiswa melakukan praktikum sesuai dengan arahan yang diberikan oleh dosen. Selama kegiatan praktik, dosen mendampingi mahasiswa sehingga kesulitan yang dialami mahasiswa dapat segera ditanyakan kepada dosen. Dalam pelaksanaan praktik tersebut terlihat ada beberapa mahasiswa yang kurang aktif dan tidak berani mengajukan pertanyaan. Proses pengambilan data pada satu kelompok membutuhkan waktu yang cukup lama karena waktu praktik yang disediakan banyak digunakan untuk mendiskusikan materi praktik.

Praktikum berjalan 150 menit, dosen mengingatkan kembali agar masing-masing kelompok mengumpulkan data praktikum. Setelah mahasiswa selesai melakukan pengambilan data kemudian mahasiswa diminta mengembalikan alat dan bahan praktik pada tempatnya dan kembali ke meja masingmasing. Dosen melakukan pengecekan data praktikum untuk setiap kelompok. Dosen melakukan umpan balik terhadap hasil praktikum mahasiswa sehingga mahasiswa mengetahui apakah data yang mereka peroleh benar atau tidak. Setelah umpan balik diberikan pada semua kelompok, dosen menyampaikan agar mahasiswa membaca teori pendukung terlebih dahulu agar praktikum dapat berjalan dengan lancar. Kegiatan pembelajaran pada siklus II selesai dan dosen menutup pembelajaran.

Setelah pembelajaran usai dilakukan refleksi atas jalannya pembelajaran yang telah dilaksanakan pada siklus II. Adapun masukan yang diberikan oleh kolabolator adalah sebagai berikut:

1. Pembelajaran siklus II terlihat lebih dinamis, mahasiswa sudah berani mengajukan pertanyaan, namun ada beberapa yang diam dan terlihat kurang siap dalam mengikuti pembelajaran. Hal ini dapat dilihat pada saat dosen memberikan pertanyaan kepada mahasiswa, hanya sedikit mahasiswa yang dapat menjawab dengan benar. Dengan demikian, dosen perlu untuk terus membangkitkan motivasi belajar mahasiswa,

2. Perlu memperhatikan keterbacaan tulisan yang ada di layar LCD sehingga mahasiswa yang duduk di barisan belakang dapat melihat dengan jelas,

3. Pertanyaan yang diajukan oleh dosen belum dapat dijawab dengan baik sehingga perlu dilakukan pre test pada pertemuan selanjutnya,

4. Umpan balik sudah diberikan oleh dosen dengan baik namun akan lebih baik jika dosen mengajak mahasiswa untuk bersama-sama merumuskan kesimpulan dari praktikum yang sudah dilaksanakan.

\section{Siklus Ketiga}

Pelaksanaan siklus ketiga diawali dengan kegiatan perencanaan (plan) yang dilakukan dengan cara melakukan koordinasi teknis pelaksanaan pembelajaran pada siklus III. Pada awal pembelajaran dosen model menyampaikan topik Praktik Rangkaian Listrik yang akan dilaksanakan. Pada siklus III, dosen model memanfaatkan LCD projector. Pada pertemuan ketiga tersebut dosen menjelaskan Job sheet tentang Resonansi seri paralel dan mencari harga reaktansi. Sebelum dilakukan pembagian kelompok, dosen mengajukan beberapa pertanyaan kepada mahasiswa. Dari beberapa pertanyaan yang disampaikan dapat dijawab oleh mahasiswa dengan baik. Dosen menampilkan jobsheet dalam layar LCD. Waktu yang digunakan untuk memberikan penjelasan atau pengantar praktikum adalah 30 menit. Setelah itu, dosen membagi mahasiswa menjadi 4 kelompok yang masing-masing kelompok terdiri atas 3 sampai 4 mahasiswa dan mahasiswa melakukan praktikum sesuai dengan arahan yang diberikan oleh dosen. Selama kegiatan praktik, dosen mendampingi mahasiswa sehingga kesulitan yang dialami mahasiswa dapat segera ditanyakan kepada 
dosen. Dalam pelaksanaan praktik tersebut mahasiswa dapat mengikuti prosedur praktikum dengan baik dan mendapatkan data dengan waktu yang relatif lebih cepat dibandingkan dengan pertemuan pada siklus I dan siklus II.

Pada saat pengambilan data praktikum selesai, dosen mengingatkan kembali agar masing-masing kelompok mengumpulkan data praktikum. Setelah mahasiswa selesai melakukan pengambilan data kemudian mahasiswa diminta mengembalikan alat dan bahan praktik pada tempatnya dan kembali ke meja masing-masing. Dosen melakukan pengecekan data praktikum untuk setiap kelompok. Dosen melakukan umpan balik terhadap hasil praktikum mahasiswa sehingga mahasiswa mengetahui apakah data yang mereka peroleh benar atau tidak. Setelah umpan balik diberikan pada semua kelompok, dosen menutup pembelajaran.
Setelah pembelajaran usai, dilakukan refleksi atas jalannya pembelajaran yang telah dilaksanakan pada siklus III. Adapun masukan yang diberikan oleh kolabolator adalah sebagai berikut:

1. Pembelajaran siklus III, mahasiswa lebih siap dalam mengikuti praktikum. Indikator kesiapan mahasiswa adalah beberapa pertanyaan yang diajukan oleh dosen dapat dijawab dengan benar dan ketika dosen memberikan pengantar praktikum, interaksi antara dosen dan mahasiswa sangat bagus dan banyak diskusi,

2. Kesimpulan praktikum dirumuskan secara bersama-sama. Dosen berperan sebagai fasilitator untuk menggiring pendapat mahasiswa pada sebuah kesimpulan.

Berdasarkan data mulai dari siklus I, siklus II, dan siklus III maka pencapaian kompetensi mahasiswa pada masing-masing siklus disajikan Gambar 1 berikut.

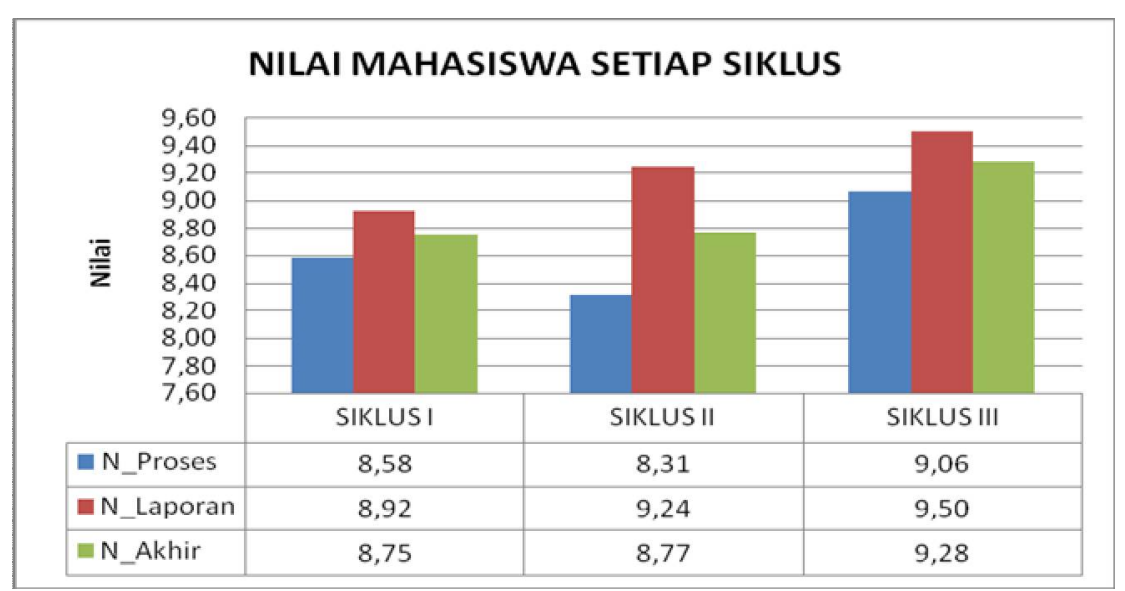

Gambar 1. Nilai Mahasiswa pada Setiap Siklus

Berdasarkan Gambar 1 dapat dilihat bahwa nilai akhir yang diperoleh pada setiap siklus mengalami peningkatan dari waktu ke waktu. Nilai rata-rata pada siklus I adalah 8,75 dan siklus II adalah 8,77. Berdasarkan kondisi tersebut terjadi peningkatan walaupun dalam angka yang cukup kecil yaitu 0,02. Pada peralihan siklus I ke siklus II, ada beberapa perubahan gaya mengajar dosen antara lain: (1) Meningkatkan motivasi belajar mahasiswa dengan cara mengingatkan kaitan penguasaan praktikum yang dilakukan dengan mata kuliah yang akan ditempuh pada semester berikutnya, (2) Penyampaian pembelajaran yang dilakukan oleh dosen lebih sistematis, judul dan tujuan praktikum disampaikan dengan jelas, apersepsi juga sudah dilakukan dengan baik, (3) Dosen memanfaatkan media berupa LCD projector untuk menyampaikan materi, (4) Pengantar singkat diberikan sebelum mahasiswa melakukan praktikum, (5) Penjelasan terhadap materi yang belum dipahami sudah dilakukan 
oleh dosen. (6) Umpan balik terhadap data hasil pengamatan sudah dilakukan, namun belum sampai merumuskan kesimpulan bersama-sama dengan mahasiswa, (7) Perhatian dosen kepada mahasiswa lebih intensif.

Dengan perubahan proses pembelajaran tersebut ternyata peningkatan hasil belajar belum memuaskan. Setelah siklus II selesai, dilanjutkan dengan siklus III dengan nilai ratarata pada siklus II adalah 8,77 dan siklus III adalah 9,28. Berdasarkan kondisi tersebut, terjadi peningkatan yang cukup tinggi yaitu 0,51. Pada peralihan siklus II ke siklus III, beberapa hal yang dilakukan dosen antara lain: (1) Pada saat apersepsi, dosen memberikan pemahaman bahwa materi praktikum saling terkait dan sangat mendukung pencapaian kompetensi mahasiswa pada mata kuliah yang akan ditempuh pada semester berikutnya, (2) Dosen memanfaatkan media berupa LCD projector dengan baik sehingga apa yang dimunculkan pada layar LCD dapat dibaca oleh mahasiswa dengan baik sehingga mahasiswa lebih memahami penjelasan yang disampaikan oleh dosen, (3) Pembelajaran yang secara sistematis dari pendahuluan, materi, dan penutup, (4) Dosen melaksanakan pre-test dengan cara menyampaikan beberapa pertanyaan kepada mahasiswa kemudian dilanjutkan dengan penyampaian teori pengantar praktikum, (5) Umpan balik terhadap data hasil pengamatan dilakukan untuk setiap kelompok dan secara bersama-sama (dosen dan mahasiswa) merumuskan kesimpulan praktikum yang telah dilaksanakan.

Dengan perubahan proses pembelajaran tersebut ternyata peningkatan hasil belajar sangat memuaskan. Berdasarkan data dan pembahasan maka dapat dilihat bahwa pencapaian kompetensi mahasiswa yang paling tinggi yaitu pada siklus III. Hal ini menunjukkan bahwa kegiatan pembelajaran Praktik Rangkaian Listrik dengan menerapkan lesson study pada penelitian ini dapat meningkatkan pencapaian kompetensi mahasiswa. Dengan demikian, diperoleh pola penerapan pembelajaran berbasis lesson study pada mata kuliah Praktik Rangkaian Listrik adalah:

1. Sebelum perkuliahan berlangsung semua mahasiswa diwajibkan mempelajari materi yang akan dipraktikkan,

2. Pada awal pembelajaran, dosen harus menyampaikan tujuan pembelajaran/praktikum yang ingin dicapai dan melakukan apersepsi dengan cara mengkaitkan topik praktikum dengan materi sebelumnya, materi pada mata kuliah lain, atau penerapannya dalam kehidupan sehari-hari,

3. Sebelum melakukan praktikum, dilakukan pretest yang bertujuan untuk melihat kesiapan mahasiswa dalam melaksanakan praktik. Pretest ini bisa dilakukan secara individu atau kelompok praktik. Pretest dapat dilakukan dengan cara dosen memberikan beberapa pertanyaan yang berkaitan dengan praktik yang akan dilakukan. Untuk efisiensi waktu, maka pretest sebaiknya dilakukan secara lisan. Selain menghemat waktu, keuntungan lainnya adalah, semua mahasiswa dapat mendengarkan pertanyaan dan jawaban sehingga mampu mengorganisasi pikirannya untuk bisa memahami bal-hal yang berkaitan dengan praktikum. Waktu yang dibutuhkan untuk pretest kurang lebih 10 menit,

4. Setelah pretest dilaksanakan dilanjutkan dengan penjelasan singkat tentang teori yang mendukung kegiatan praktik. Penjelasan ini dapat diberikan kurang lebih 15 menit,

5. Kegiatan praktikum dilaksanakan secara berkelompok yang terdiri dari 3 sampai 4 mahasiswa. Anggota kelompok praktik untuk setiap job sebaiknya tidak sama sehingga dosen dapat melihat pencapaian kompetensi setiap individu,

6. Setiap kelompok diberi tugas melakukan praktik sesuai dengan prosedur, mencatat data hasil eksperimen, membuat laporan sementara dan dikumpulkan pada saat selesai praktikum, 
7. Dosen memberikan umpan balik terhadap data sementara yang dikumpulkan mahasiswa sehingga mahasiswa dapat mengetahui apakah praktik yang dilakukan memberikan data yang benar atau tidak,

8. Setelah praktikum selesai, setiap mahasiswa diwajibkan untuk menganalisis data lebih lanjut dan dituangkan dalam laporan praktikum yang sifatnya individu. Laporan individu dikumpulkan pada minggu berikutnya sebagai syarat untuk mengikuti pembelajaran berikutnya.

\section{KESIMPULAN DAN SARAN}

Pola penerapan pembelajaran berbasis lesson study pada mata kuliah Praktik Rangkaian Listrik adalah sebagai berikut: (a) sebelum praktik, mahasiswa diwajibkan mempelajari materi; (b) pada awal pembelajaran, dosen menjelaskan tujuan pembelajaran/praktikum dan melakukan apersepsi; (c) memberikan pretest; (d) membagi kelompok praktik dengan jumlah anggota 3-4 orang; (e) mahasiswa menyerahkan data eksperimen; (f) dosen memberikan umpan balik terhadap data eksperimen; dan (g) mahasiswa menganalisis data dan membuat laporan individu.

Kompetensi yang dicapai mahasiswa pada mata kuliah Praktik Rangkaian Listrik yang dalam perkuliahannya menerapkan pembelajaran berbasis lesson study yang ditandai dengan rata-rata capaian nilai mahasiswa yang meningkat dari siklus I ke siklus II, dan siklus II ke siklus III. Adapun pencapaian nilai rata-rata untuk siklus I adalah 8,75 , siklus II adalah 8,77 , dan siklus III adalah 9,28 .

Saran untuk lebih meningkatkan kompetensi mahasiswa pada mata kuliah praktik Rangkaian Listrik, adalah sebagai berikut: (1) Perlu penambahan unit alat praktikum untuk mendukung mata kuliah Praktik Rangkaian Listrik. Adapun peralatan yang sangat dibutuhkan adalah: $A F G$ (Audio Function Generator), CRO (Cathode-Ray Oscilloscope), dan probe CRO, (2) Kompetensi mahasiswa dalam mata kuliah praktikum dapat ditingkatkan dengan cara melakukan pretest kepada mahasiswa sehingga mahasiswa lebih siap untuk melakukan praktikum, (3) Buku, diktat, dan sumber belajar penunjang lebih ditingkatkan termasuk sumber belajar online.

\section{DAFTAR PUSTAKA}

Lewis, Catherine C. (2002). Lesson Study: A Handbook of Teacher-Led Instructional Change. Philadelphia, PA: Research for Better Schools, Inc.

Richardson, J.(2006). Lesson Study: Teacher Learn How to Improve Instruction. National Staff Development Council. Diunduh dari: http://www.nsd.org.03/05/06.

Robinson, Naomi (2006). Lesson Study: An Example of Its Adaptation to Israeli Middle School Teacher. Diunduh dari: http://www. stwww.weizmann.ac.il/Gmath/ICMI/Robinson_proposal.doc.

Stigler, J. W., \& Hiebert, J. (1999). The teaching gap: Best ideas from the world's teachers for improving education in the classroom. New York: The Free Press

Sukirman. (2006). Lesson Study, Yogyakarta: FMIPA UNY.

Wang Iverson, Patsy \& Yoshida, Makoto (Editors). (2005). Building Our Understanding of Lesson Study. Philadelphia, PA: Research for Better Schools. 